\title{
CARDIAC OUTPUT, BLOOD AND INTERSTITIAL FLUID VOLUMES, TOTAL CIRCULATING SERUM PROTEIN, AND KIDNEY FUNCTION DURING CARDIAC FAILURE AND AFTER IMPROVEMENT ${ }^{1}$
}

\author{
BY WM. B. SEYMOUR, WALTER H. PRITCHARD, L. P. LONGLEY, \\ AND J. M. HAYMAN, JR. \\ (From the Department of Medicine, Western Reserve University, and the Medical Service, \\ Lakeside Hospital, Cleveland)
}

(Received for publication October 14, 1941)

The relation of cardiac output, blood and interstitial fluid volumes, plasma protein concentration, and kidney function in heart failure is still a subject of investigation. The majority of investigators in this country $(1,2)$ and in England (3, 4) have believed that the fundamental factor in heart failure is a diminished cardiac output for a given diastolic size against a given resistance, and that increase in venous pressure and blood volume are secondary phenomena, although themselves responsible for many of the symptoms of heart failure. Diminished cardiac output would first be manifested by failure to meet the oxygen requirements of the body during exercise, and only in extreme cases by a subnormal cardiac output at rest. Thus, measurements of cardiac output at rest would only be below normal in patients who showed symptoms of heart failure at rest. Since, however, even in this group Harrison (5) found the average values for cardiac output, as well as the range, similar to those in the compensated group, he concluded that diminished cardiac output was not an important factor in cardiac failure and developed his "Backward Failure" theory, attributing the major phenomenon of cardiac failure to increased venous pressure proximal to the failing (but still normally working) chamber.

The oliguria and nitrogen retention of cardiac failure are attributed to passive congestion by Harrison (6) and to "extrarenal" deviation of water by Fishberg (7). Neither of these explanations is satisfactory. Increase in renal venous pressure only results in oliguria when renal blood flow is reduced. If blood flow is unchanged, increase in renal venous pressure results in diuresis (8). If the oliguria is due to diminished water available

1 The expenses of this investigation were defrayed by a grant from the Commonwealth Fund. for excretion, this must be caused either by reduction in renal blood flow or increase in plasma protein concentration. The latter is contrary to observation.

Because of the complexities of cardiac failure, and adventitious phenomena such as elevation in metabolic rate, psychic disturbances, etc., it would seem that data obtained on the same patient when in failure and when compensated are more readily interpreted than statistical conclusions on different groups. Stewart and Cohn (1) studied the effect of digitalis in this way and found an increase in cardiac output and decrease in heart size with compensation. Friedman, Clark, Resnik, and Harrison (5) found no consistent change in cardiac output, stroke volume, arteriovenous oxygen difference, or basal metabolic rate with clinical improvement. Grollman's acetylene method (9) was employed in both investigations to measure cardiac output.

The present report concerns measurements of cardiac output, blood volume, interstitial fluid volume, plasma proteins, renal function, and other aspects of the circulation in a small group of patients when suffering from cardiac failure and again after restoration of compensation.

The patients all had definite congestive heart failure due to hypertensive or arteriosclerotic heart disease. Patients with aortic insufficiency or auricular fibrillation were not considered suitable for this study because of the method employed for estimating cardiac output. The first series of observations was made as soon as possible after admission before treatment, save for indicated sedatives and hypnotics. Estimations of cardiac output under standard conditions of bed rest and no food for fourteen hours were made on one morning, followed by estimations of blood and interstitial 
fluid volumes, etc. The following day measurements of kidney function were carried out. The patient was then given full doses of digitalis and, if necessary, additional diuretics, and the observations were repeated when the subject was free from edema and other symptoms and was at rest or up and about the ward.

The data are presented under three headings: I. Cardiac output, blood pressure, and venous pressure. II. Blood and interstitial fluid volume, plasma protein concentration, and total circulating plasma proteins. III. Kidney function.

\section{Cardiac output}

In order to avoid the necessity of the patient's cooperation and the uncertainty of obtaining equilibrium in a bag-lung system before re-circulation, cardiac output was estimated by Bazett's method (10). While the constants utilized are empirically derived, the cardiac index of normal individuals by this method checks closely with the acetylene method which gives a value of $2.2 \pm 0.3$ for normal subjects under basal conditions. Since the same values for aortic area and artery length were used for calculation of output before and after compensation, an error in these might affect the absolute, but not the relative values.

Bazett's method is based on von Recklinghausen's principle that "the volume of blood leaving the arterial tree, and the distensibility of the system are the sole determinants of the fall in pressure in diastole." Since the blood leaving the arterial tree in the "systolic" period should be related to that leaving in diastole, according to the relative pressures in and the relative duration of these periods, calculation of the volume leaving in the "systolic" period is possible (10) if we accept the data of Whittaker and Winton (11). The total volume or stroke volume is then easily obtained.

1. Vd (blood leaving in diastole)

$$
=\frac{12.7}{100} \times Z-D \times\left[\frac{V^{1}}{v_{1}^{2}}+\frac{V^{2}}{v_{2}^{2}}+\frac{V^{3}}{v_{3}^{2}}+\frac{V^{4}}{v_{4}^{2}}\right]
$$

2. $V s$ (blood leaving in systole) $=V d \times \frac{s}{d} \times \frac{M s-20}{M d-20}$

3. $V t$ (stroke volume) $=V s+V d$

4. C.O. (cardiac output) $=V t \times$ pulse rate

5. C.I. (cardiac index) $=\frac{\text { C.O. }}{\text { S.A. }}$

In these formulae, the following representations exist: $Z=$ dicrotic pressure; $D=$ diastolic pressure; $V^{\mathbf{1}}, V^{\mathbf{2}}$, etc. $=$ vessel volumes assumed by calculations from sur. face area and aortic areas; $v_{1}, v_{2}$, etc. $=$ pulse velocities for the corresponding volume sections; $s$ and $d$ are "systolic" and "diastolic" periods; $M s$ and $M d$ represent the mean pressures of the respective $s$ and $d$ periods. $^{2}$

To obtain $S, Z$, and $D$ pressures, a one- or three-bag compression system recording optically was first used. At these pressures, various criteria became apparent on the recorded volume brachial pulse curve. The value assigned to $Z$ was calculated from the ratio of the heights of perpendiculars from the point of maximum elevation and from the top of the dicrotic notch. Later, in order to record more accurately all pressures, the bag-compression system was replaced by direct brachial arterial puncture under local anesthesia with a Gregg (12) needle optical manometer. A short number 22 needle was employed. That this arterial puncture did not disturb the patients is attested to by the fact that pulse rates taken during the procedure showed no, or only very slight, elevation over those recorded during the taking of pulse wave velocities.

Vessel volumes $V^{1}, V^{2}$, etc., were computed from formulae utilizing Bazett's graph of aortic area, surface area, and height. Weights used were taken in the edema-free state and used in all calculations of output on the same patient.

For recording pulse wave velocities $v_{1}, v_{3}$, etc., simple cup or glycerine tambours were held or fastened over the appropriate vessels and cardiac area. Each tambour was connected by equal length rubber tubing to segment capsules held in an Everbach triple segment capsule holder, avoiding parallax. Projection distance from capsules to recording camera was 1.25 to 1.5 meters. The actual distances traveled between tambours on the vessels were calculated by use of other predetermined constants (10).

Since the accuracy of the method depends considerably on the identification in the records of the start of ventricular discharge, heart sounds were substituted for sternal pulsations, but recordings of the electrocardiogram, apex beat, and heart sounds simultaneously with the subclavian pulse were made in many instances. The difficulty of denoting time of ejection is great, but the same criteria in the same patient were used at all times, although these varied in configuration among the individual patients.

The "diastolic" period was measured from the top of the dicrotic wave to the end of the pulse cycle; the rest was considered systolic.

Mean pressures were calculated from the brachial pressure curves by weighing or by use of a planimeter. All pressures recorded represent the mean of from 6 to 54 determinations, the greater number being those of the pressure pulses derived from direct arterial puncture. Pulse wave velocities are expressed as means of from 5 to 10 determinations.

Venous pressures were determined by using the method and auricular reference point of Lyons, Kennedy, and Burwell (13).

2 It is advised that for full consideration in the use of this method Bazett's original paper be consulted. 
TABLE I

Comparison of cardiac output estimated by Bazett's method and by acetylene method, and agreement of Barett's method on different days

\begin{tabular}{|c|c|c|c|c|c|c|c|c|c|c|c|c|c|c|c|c|}
\hline \multirow{2}{*}{$\frac{\text { Patient }}{\text { Date }}$} & \multirow{2}{*}{$\frac{\text { Age }}{\text { S.A. }}$} & \multirow{2}{*}{$P$} & \multirow{2}{*}{$s$} & \multirow{2}{*}{$z$} & \multirow{2}{*}{$D$} & \multirow{2}{*}{$Z-D$} & \multirow{2}{*}{ M.P. } & \multirow{2}{*}{$P V_{1}$} & \multirow{2}{*}{$P V_{2}$} & \multirow{2}{*}{$P V_{3}$} & \multirow{2}{*}{ s.v. } & \multirow{2}{*}{ c.o. } & \multirow{2}{*}{ C.I. } & \multirow{2}{*}{$R$} & \multicolumn{2}{|c|}{ Acetylene } \\
\hline & & & & & & & & & & & & & & & c.o. & C.I. \\
\hline$\frac{1 .}{\text { September } 11,1939}$ & $\frac{25}{1.92}$ & 51 & 102 & 76 & 51 & 25 & 75 & 3.5 & 5.9 & 4.4 & 85 & 4.3 & 2.3 & 98 & 4.6 & 2.4 \\
\hline 2. & 27 & & & & & & & & & & & & & & & \\
\hline October $\quad 21,1939$ & 2.25 & 0 & 110 & $\begin{array}{l}91 \\
\end{array}$ & 01 & 30 & 10 & 4.0 & J.2 & 1.0 & 80 & 0.2 & 2.0 & 102 & 3.0 & 2.0 \\
\hline$\frac{3 .}{\text { September } 22,1939}$ & $\frac{28}{1.74}$ & 60 & 111 & 97 & 69 & 28 & 92 & 5.0 & 4.7 & 7.3 & 67 & 4.0 & 2.3 & 120 & 4.0 & 2.3 \\
\hline & & 62 & 94 & 76 & 51 & 24 & 76 & 4.2 & 4.0 & 5.5 & 59 & 3.6 & 2.1 & 109 & 4.0 & 2.3 \\
\hline 4. & 45 & 76 & 116 & 77 & 50 & 10 & 70 & $=0$ & 57 & 70 & (1) & 2, & & & & \\
\hline February 12,1941 & 1.55 & 80 & 180 & 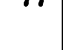 & 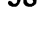 & 17 & 17 & 0.0 & 0.0 & 1.0 & 71 & 0.1 & 2.1 & 110 & & \\
\hline 5. & 17 & 01 & 126 & & & & 00 & & & & & & & & & \\
\hline 10,1941 & 1.76 & 01 & 100 & 92 & 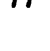 & 10 & $8 y$ & 0.0 & 0.2 & 0.0 & 30 & 0.1 & 1.0 & 100 & & \\
\hline April $\quad 23,1941$ & & 81 & 139 & 100 & 81 & 19 & 101 & 5.0 & 5.7 & 5.8 & 40 & 3.3 & 1.9 & 160 & & \\
\hline 3,1941 & & 81 & 134 & 94 & 77 & 17 & 97 & 4.5 & 5.3 & 6.3 & 40 & 3.3 & 1.9 & 153 & & \\
\hline 6. & 28 & & & & & & & & & & & & & & & \\
\hline November 1,1939 & 1.67 & 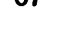 & 100 & 30 & 11 & 22 & 30 & 7.0 & 0.0 & 1.2 & 78 & 0.0 & 2.0 & 170 & & \\
\hline November 5,1939 & & 65 & 104 & 95 & 66 & 29 & 90 & 3.7 & 6.8 & 7.8 & 48 & 3.1 & 1.9 & 142 & & \\
\hline January $\quad 12,1940$ & & 59 & 104 & 90 & 64 & 26 & 86 & 3.5 & 5.3 & 6.5 & 57 & 3.4 & 2.0 & 129 & & \\
\hline 1,1940 & & 61 & 106 & 93 & 68 & 25 & 88 & 3.9 & 6.3 & 7.0 & 43 & 2.7 & 1.6 & 165 & & \\
\hline
\end{tabular}

The following abbreviations are used in this and subsequent tables: S.A. = surface area in square meters; $P=$ pulse rate per minute; $S=$ systolic blood pressure in $\mathrm{mm} \mathrm{Hg} Z Z=$ dicrotic blood pressure; $D=$ diastolic blood pressure; M.P. = mean blood pressure; $P V_{1}=$ pulse wave velocity heart to subclavian artery; $P V_{2}=$ pulse wave velocity heart to femoral artery $-P V_{1} ; P V_{3}=$ pulse wave velocity subclavian to brachial arteries; $\mathrm{S}$.V. $=$ stroke volume in $c c$. per beat; C.O. = cardiac output in liters per minute; C.I. = cardiac index, liters per square meter; $R=$ effective peripheral resistance in arbitrary units.

Although this method of measuring cardiac output is physiological in its principles, it is entirely empirical in its application as all constants used have been adjusted by Bazett to give good agreement in normal subjects with values of cardiac output determined simultaneously with acetylene. The results in our hands on normal adults are shown in Table I. The table also shows the agreement in estimated cardiac output in two subjects on different days and in the last subject at longer intervals.

Three patients with thyrotoxicosis were also studied before and after thyroidectomy to test the method's ability to detect changes known to occur in this disease (9). These data are presented in Table II. Values of cardiac output were all above normal during the active phase of the syndrome, the elevation being dependent upon the tachycardia as the stroke volume remained the same.

The data from the six cardiac patients are given in Table III. All of the six patients showed significant reductions in stroke volume and minute output while in failure. The pulse rates were all faster during failure, but in only one was the rate above 90 .

From the data in Table III, the mechanism of the reduced output in failure is evident. While the pressure difference in the $d$ period $(Z-D)$ was 
WM. B. SEymour, Walter h. PRitchard, L. P. LONgley, AND J. M. hayman, JR.

TABLE II

Estimations of cardiac output before and after thyroidectomy for hyperthyroidism

\begin{tabular}{|c|c|c|c|c|c|c|c|c|c|c|c|c|c|c|}
\hline$\frac{\text { Patient }}{\text { Age }}$ & & $P$ & $S$ & $z$ & $D$ & $Z-D$ & $P V_{1}$ & $P V_{2}$ & $P V_{3}$ & S.V. & c.o. & C.I. & $R$ & BMR \\
\hline 1. & Before & 107 & 103 & 93 & 73 & 20 & 4.6 & 5.2 & 6.6 & 49 & 5.3 & 3.3 & 89 & +54 \\
\hline 22 & After & 73 & 135 & 98 & 73 & 25 & 4.6 & 4.9 & 5.3 & 50 & 3.7 & 2.3 & 126 & +6 \\
\hline 2. & Before & 97 & 115 & 79 & 60 & 19 & 4.5 & 6.9 & 7.3 & 46 & 4.5 & 3.0 & 81 & +42 \\
\hline 49 & After & 68 & 129 & 98 & 72 & 26 & 4.7 & 6.2 & 9.1 & 46 & 3.1 & 2.1 & 136 & +15 \\
\hline 3. & Before & 124 & 114 & 76 & 61 & 15 & 4.6 & 5.1 & 6.8 & 40 & 5.0 & 2.9 & 86 & +60 \\
\hline 30 & After & 77 & 123 & 85 & 67 & 18 & 4.5 & 6.2 & 7.5 & 38 & 2.9 & 1.7 & 159 & +5 \\
\hline
\end{tabular}

$\mathrm{BMR}=$ basal metabolic rate.

somewhat reduced in all but Patient 1 , the major change occurred in the pulse wave velocities, which were uniformly increased during failure. ${ }^{3}$ Velocities after recovery became slower in both the larger and smaller vessels.

The blood pressure changes are of interest. In all but Patient 3, the diastolic pressures were lower after recovery. Systolic pressures likewise fell in four, but rose in two. Since the mean pressure is determined by the cardiac output and the mean

${ }^{3}$ Except for $P V_{2}$ in Patient 2, the difference in velocity during and after failure is at least seven times the standard error of the difference. peripheral resistance, this latter may be calculated from the relation of mean pressure to cardiac index

$$
\left(R=K \frac{M}{\text { C.I. }}\right)
$$

If $K$ be assigned an arbitrary value of 3 , the values for normal young adults range from 80 to 120 (10). The calculated effective resistances were much increased in failure compared to their recovery levels. The decrease in cardiac output and the increase in mean pressure both contribute to the increase in the ratio.

TAB LE III

Changes in pulse rate, blood pressure, and cardiac output during congestive heart failure and after recovery of compensation

\begin{tabular}{|c|c|c|c|c|c|c|c|c|c|c|c|c|c|c|c|}
\hline$\frac{\text { Patient }}{\text { Age }}$ & & $\boldsymbol{P}$ & $S$ & $Z$ & $D$ & $M P$ & $Z-D$ & $P V_{1}$ & $P V_{2}$ & $P V_{2}$ & S.V. & c.o. & C.I. & $\boldsymbol{R}$ & V.P. \\
\hline 1. F. T. & Before & 80 & 240 & 205 & 144 & 168 & 61 & 9.6 & 17.3 & 16.9 & 28 & 2.3 & 1.3 & 455 & 35 \\
\hline 66 & After & 59 & 172 & 143 & 83 & 128 & 62 & 4.8 & 12.0 & 12.0 & 66 & 3.9 & 2.3 & 170 & 10 \\
\hline 2. P. K. & Before & 74 & 151 & 113 & 81 & 109 & 32 & 5.2 & 10.9 & 10.8 & 39 & 2.9 & 1.6 & 206 & 35 \\
\hline 70 & After & 54 & 141 & 110 & 70 & 100 & 40 & 4.3 & 10.9 & 8.6 & 71 & 3.9 & 2.1 & 144 & 7 \\
\hline 3. J.F. & Before & 84 & 151 & 125 & 87 & 121 & 38 & 8.4 & 10.1 & 12.1 & 30 & 2.5 & 1.6 & 232 & 20 \\
\hline 72 & After & 70 & 179 & 138 & 85 & 125 & 53 & 6.1 & 8.1 & 10.4 & 50 & 3.5 & 2.2 & 173 & 7 \\
\hline 4. W. T. & Before & 81 & 163 & 142 & 111 & 140 & 31 & 4.8 & 9.8 & 15.8 & 34 & 2.7 & 1.8 & 240 & 25 \\
\hline 50 & After & 64 & 135 & 118 & 83 & 108 & 35 & 3.8 & 6.6 & 9.0 & 57 & 3.6 & 2.4 & 137 & 6 \\
\hline 5. M. A. & Before & 97 & 147 & 126 & 102 & 123 & 24 & 5.9 & 9.7 & 8.7 & 33 & 3.1 & 1.7 & 190 & 26 \\
\hline 70 & After & 82 & 125 & 104 & 77 & 101 & 27 & 5.2 & 7.0 & 7.2 & 47 & 3.9 & 2.2 & 138 & 12 \\
\hline 6. J. Y. & Before & 81 & 136 & 108 & 78 & 101 & 30 & 8.8 & 7.6 & 10.0 & 26 & 2.1 & 1.3 & 234 & 30 \\
\hline 65 & After & 63 & 145 & 94 & 56 & 84 & 38 & 6.3 & 5.9 & 7.0 & 61 & 3.9 & 2.4 & 105 & 10 \\
\hline
\end{tabular}


Venous pressures were markedly elevated during failure in all patients, and in those in whom circulation times were done these were likewise prolonged. The size of the heart was larger during failure in the four patients who had $x$-ray studies before and after failure.

In this group of patients, cardiac insufficiency was manifested by marked reduction in stroke volumes and significant decreases in the total minute discharge in spite of higher pulse rates. These changes have been calculated from the data of peripheral phenomena accompanying this state. The total "run-off" of blood from the arterial tree was less in failure in spite of higher blood pressures. This is reflected in the reduced elasticity of the larger central and peripheral arteries which are more distended at the higher pressures and in the lower effective pressure head in the $d$ period $(Z-D)(14)$.

That peripheral vasoconstriction was present must be inferred since both diastolic pressures and the effective peripheral resistances $(R)$ were higher during failure. This vasoconstriction would actually reduce the total arterial crosssectional area in spite of distention of the large arterial trunks.

Although the volume of blood discharged per beat was lower during failure and was uncompensated by a rise in pulse rate, the total volume of blood in the vascular system was greater (see Section II). With reduced capacity of the total arterial tree, this excess volume must have been accommodated within the venous system.

It seems improbable that sufficient blood could be transferred to the distensible venous system (15) by arteriolar constriction to account for the elevated venous pressures during failure if blood volume were normal. The increased blood volume, rather than redistribution of a constant volume of blood, would seem to be the major factor in producing the elevated venous pressure (16). This hypothesis is supported by another patient with coronary occlusion and minimal congestive failure who showed no change in venous pressure or in blood volume with improvement. At the first determination her cardiac index was 1.65 , peripheral resistance 167 , and venous pressure 12 $\mathrm{cm}$. of saline. After improvement, her cardiac index was 2.2 , peripheral resistance 130 , and venous pressure $14 \mathrm{~cm}$. saline.
These findings are consistent with Harrison's assignment of the symptoms of congestive failure to increased ventricular diastolic resistance, leading to retrograde stasis. Such increased ventricular resistance can only be due to pericardial adhesions, incomplete diastolic relaxation, or to blood remaining in the ventricle from incomplete emptying. There is no evidence for the first two of these. Our findings differ from Harrison's in the consistency of a diminished cardiac output during failure.

\section{Variations in blood and extracellular fluid volumes and in plasma proteins}

It has been shown by several investigators (17 to 25) that the majority of patients in cardiac failure have a reduced quantity of protein per unit volume of serum. Of 261 cases culled from the literature and other sources, 212 , or 81.2 per cent, showed a total serum protein of less than 6.6 grams per 100 cubic centimeters, with a mean total serum protein of 5.67 grams per $100 \mathrm{cc}$. The reduction is due almost exclusively to a drop in serum albumin; of 127 cases in which the protein fractions were determined $(17,19,20,21$, $22,25), 117$, or 92.6 per cent, showed a serum albumin of less than 4.6 grams with a mean serum albumin concentration of 3.41 grams per $100 \mathrm{cc}$.

Three primary factors could be responsible for a reduction of serum protein: inadequate protein intake, excessive protein loss, and failure of protein synthesis (26). All three of these may operate in cardiac failure. Furthermore, it has never been shown whether the reduction of serum albumin in cardiac failure is real or only apparent since an increase in serum volume regularly occurs in this condition (27) with possible dilution of serum protein. Patients who are suffering from their first bout of cardiac failure and who have been eating ordinary diets do not usually experience a prolonged anorexia preceding failure, so that inadequate protein intake would seem improbable as a major cause of hypoproteinemia; the same thought holds for impairment of protein synthesis. The loss of protein in the urine of these patients is usually slight. Two other possibilities remain: loss of protein into tissue spaces, and blood dilution. Attention was therefore directed toward these two factors. 
The following determinations were made on each patient during the phase of cardiac failure and at maximal recovery: total blood volume, serum volume, interstitial fluid volume, hematocrit, serum proteins, and edema fluid proteins.

Total blood volume and serum volume were determined by the Evans Blue dye method as modified by Gibson and Evans (28). A Pulfrich photometer with an S-62 filter and a cell $1 \mathrm{~cm}$. thick was used for estimations of the concentration of dye in the serum.

Extracellular fluid volume was determined by the thiocyanate method of Lavietes et al. (29). Potassium thiocyanate was given by mouth twenty-four hours before the determination. The concentration of thiocyanate in serum was determined with a Pulfrich photometer, using an $\mathrm{S}-47$ filter and a cell $1 \mathrm{~cm}$. thick. In most instances, the concentration of thiocyanate in extracellular fluid itself was also determined.

Hematocrits were determined in the Wintrobe tube, using either heparin or a mixture of ammonium and potassium oxalate, $2 \mathrm{mgm}$. per $1 \mathrm{cc}$. of blood, as anticoagulant, and centrifuged until the volume of cells was constant. Serum proteins were determined by Robinson's modification (30) of Howe's micromethod. Extracellular fluid proteins were determined in the same way. All specimens were done in triplicate. Extracellular fluid was obtained by means of Southey tubes. All blood was taken under oil and without stasis.

The data are given in Table IV. In all patients, total blood and serum volume values were increased during cardiac failure, the mean change in total blood volume with compensation being 1.15 liters, or 25.0 per cent. Gibson and Evans (27), studying a similar group of patients, found a mean increase of 22.3 per cent. They found that in extreme decompensation the mean increase was 55.3 per cent; but among these the distribution was very wide, eight out of fourteen showing an increase in blood volume of less than 35 per cent. In Gibson and Evans' series, red cells and serum participated equally in the increase, but this was not so in our cases since four out of six showed a considerable rise in hematocrit with compensation, and the increase of serum volume in failure was relatively much greater than total blood volume, averaging 0.92 liter, or 35 per cent. Blood volumes in the compensated phase were normal

TABLE IV

Summary of data on cases

\begin{tabular}{|c|c|c|c|c|c|c|c|c|c|c|}
\hline & Case & Weight & $\begin{array}{l}\text { Blood } \\
\text { volume }\end{array}$ & $\begin{array}{l}\text { Serum } \\
\text { volume }\end{array}$ & $\begin{array}{l}\text { Total } \\
\text { extracel- } \\
\text { lular fluid }\end{array}$ & $\begin{array}{c}\text { Serum } \\
\text { total } \\
\text { protein }\end{array}$ & $\begin{array}{l}\text { Serum } \\
\text { albumin }\end{array}$ & $\begin{array}{l}\text { Serum } \\
\text { globulin }\end{array}$ & $\begin{array}{c}\text { Edema } \\
\text { fluid } \\
\text { protein }\end{array}$ & Hematocrit \\
\hline \multirow[t]{2}{*}{ 1. F. T. } & $\begin{array}{l}\text { Onset.......... } \\
\text { Recovery..... }\end{array}$ & $\begin{array}{l}\text { kgm. } \\
81.4 \\
70.0\end{array}$ & $\begin{array}{l}\text { liters } \\
6.60 \\
5.30\end{array}$ & $\begin{array}{l}\text { liters } \\
3.82 \\
3.20\end{array}$ & $\begin{array}{c}\text { liters } \\
31.8 \\
16.9\end{array}$ & $\begin{array}{r}\text { grams } \\
\text { per cent } \\
6.98 \\
7.00\end{array}$ & $\begin{array}{l}4.26 \\
3.69\end{array}$ & $\begin{array}{l}2.72 \\
3.31\end{array}$ & 0.18 & $\begin{array}{l}42 \\
40\end{array}$ \\
\hline & Difference..... & 11.4 & -1.30 & -0.62 & -14.9 & +.02 & -0.57 & +0.59 & & \\
\hline \multirow[t]{2}{*}{ 2. P. K. } & $\begin{array}{l}\text { Onset.......... } \\
\text { Recovery..... }\end{array}$ & $\begin{array}{l}87.0 \\
75.5\end{array}$ & $\begin{array}{l}5.88 \\
5.43\end{array}$ & $\begin{array}{l}3.88 \\
3.04\end{array}$ & $\begin{array}{l}32.9 \\
21.7\end{array}$ & $\begin{array}{l}6.95 \\
7.18\end{array}$ & $\begin{array}{l}4.57 \\
4.41\end{array}$ & $\begin{array}{l}2.38 \\
2.77\end{array}$ & 0.67 & $\begin{array}{l}34 \\
44\end{array}$ \\
\hline & Difference..... & 11.5 & -0.45 & -0.84 & -11.2 & +0.23 & -0.16 & +0.39 & & \\
\hline \multirow[t]{2}{*}{ 3. J. F. } & $\begin{array}{l}\text { Onset.......... } \\
\text { Recovery...... }\end{array}$ & $\begin{array}{l}61.4 \\
50.8\end{array}$ & $\begin{array}{l}5.23 \\
3.96\end{array}$ & $\begin{array}{l}3.97 \\
2.57\end{array}$ & $\begin{array}{l}26.9 \\
18.6\end{array}$ & $\begin{array}{l}6.07 \\
7.50\end{array}$ & $\begin{array}{l}3.39 \\
4.21\end{array}$ & $\begin{array}{l}2.68 \\
3.29\end{array}$ & $0.96^{*}$ & $\begin{array}{l}24 \\
35\end{array}$ \\
\hline & Difference..... & 10.6 & -1.27 & -1.40 & -8.3 & +1.43 & +0.82 & +0.61 & & \\
\hline \multirow[t]{2}{*}{ 4. W. T. } & $\begin{array}{l}\text { Onset........... } \\
\text { Recovery..... }\end{array}$ & $\begin{array}{l}72.0 \\
51.7\end{array}$ & $\begin{array}{l}5.75 \\
4.20\end{array}$ & $\begin{array}{l}3.50 \\
2.35\end{array}$ & $\begin{array}{l}38.8 \\
18.8\end{array}$ & $\begin{array}{l}6.57 \\
7.35\end{array}$ & $\begin{array}{l}3.81 \\
3.84\end{array}$ & $\begin{array}{l}2.76 \\
3.51\end{array}$ & 0.39 & $\begin{array}{l}39 \\
44\end{array}$ \\
\hline & Difference..... & -20.3 & -1.55 & -1.15 & -20.0 & +0.78 & +0.03 & +0.75 & & \\
\hline \multirow[t]{2}{*}{ 5. M. A. } & $\begin{array}{l}\text { Onset........... } \\
\text { Recovery...... }\end{array}$ & $\begin{array}{r}100.5 \\
73.5\end{array}$ & $\begin{array}{l}5.75 \\
5.00\end{array}$ & $\begin{array}{l}2.88 \\
2.35\end{array}$ & $\begin{array}{l}38.6 \\
20.8\end{array}$ & $\begin{array}{l}6.42 \\
7.52\end{array}$ & $\begin{array}{l}4.34 \\
4.70\end{array}$ & $\begin{array}{l}2.08 \\
2.82\end{array}$ & 0.85 & $\begin{array}{l}49 \\
53\end{array}$ \\
\hline & Difference..... & -27.0 & -0.75 & -0.53 & -17.8 & +1.10 & +0.36 & +0.74 & & \\
\hline \multirow[t]{2}{*}{ 6. J.Y. } & $\begin{array}{l}\text { Onset.......... } \\
\text { Recovery..... }\end{array}$ & $\begin{array}{l}70.4 \\
54.4\end{array}$ & $\begin{array}{l}5.33 \\
3.67\end{array}$ & $\begin{array}{l}3.26 \\
2.29\end{array}$ & $\begin{array}{l}28.5 \\
19.1\end{array}$ & $\begin{array}{l}6.04 \\
6.73\end{array}$ & $\begin{array}{l}3.97 \\
4.16\end{array}$ & $\begin{array}{l}2.07 \\
2.57\end{array}$ & 0.25 & $\begin{array}{l}39 \\
38\end{array}$ \\
\hline & Difference..... & -16.0 & -1.66 & -0.97 & -9.4 & +0.69 & +0.19 & +0.50 & & \\
\hline
\end{tabular}

* Pleural fluid. 
when compared with the values of Gibson and Evans (28).

Extracellular fluid volume decreased with recovery in all cases, the mean change being 12.73 liters. The mean value of total extracellular fluid in the recovery phase was 32 per cent of total body weight-still almost 50 per cent above normal. Decrease in weight occurred with recovery in all of the patients, the mean loss being $15.6 \mathrm{kgm}$.

Serum protein values, in terms of grams per $100 \mathrm{cc}$. of serum, increased with recovery in all cases, the increase being ascribable mainly to the globulin fraction. This change is only in concentration, for when total circulating serum proteins are calculated, the amount of serum albumin actually decreased markedly and the serum globulin decreased slightly.

The changes observed in blood volume are similar to those found in previous studies on similar cases (27). The increase in blood volume in our cases was more of a "hydremic plethora" than in the cases of Gibson and Evans, as in our cases serum volume was the maximum participant in this change. Presumably, the vascular bed, mainly the venous side, increases in capacity to accommodate this increased volume (15).

Similarly, the changes in total extracellular fluid and weight are those commonly observed in recovery from cardiac failure. Although the two were generally in agreement, the apparent discrepancies are difficult to explain.

As noted, the final value of total extracellular fluid averaged 32 per cent of body weight, even though the patients showed no demonstrable edema. It is unlikely that this can be accounted for wholly on the basis of cardiac insufficiency, since by all other criteria cardiac compensation was much improved. We feel that this retention of fluid may be a peripheral effect for two reasons: (1) although anoxia causes an increase in capillary permeability (31), the time required for recovery may be prolonged; (2) the protein left in extracellular space may be picked up much more slowly via the lymphatics than water is by the capillaries. In the latter event, effective osmotic "pull" of water back into the blood stream would be reduced, since the remaining protein in extracellular space would exert a counter pressure.

Although serum proteins rose in value in terms of grams per 100 cc., actually the amount of circulating protein decreased. In Table $\mathrm{V}$, the total amounts of albumin and globulin, calculated by multiplying grams per cent by serum volume, are presented at onset and with recovery and the difference in these two values is recorded.

TABLE $v$

Total circulating proteins in failure and compensation with net changes

\begin{tabular}{l|r|r|r|r|r|r}
\hline \hline & \multicolumn{2}{|c|}{ Decompensation } & \multicolumn{2}{c|}{ Compensation } & \multicolumn{2}{c}{ Net change } \\
\cline { 2 - 5 } & $\begin{array}{c}\text { Total } \\
\text { albumin }\end{array}$ & $\begin{array}{c}\text { Total } \\
\text { globulin }\end{array}$ & $\begin{array}{c}\text { Total } \\
\text { albumin }\end{array}$ & $\begin{array}{c}\text { Total } \\
\text { globulin }\end{array}$ & Albumin & Globulin \\
\hline & grams & grams & grams & grams & grams & grams \\
1. & 162.5 & 105.0 & 118.0 & 106.0 & -44.5 & +1.0 \\
2. & 176.0 & 92.5 & 134.0 & 84.3 & -42.0 & -8.2 \\
3. & 134.5 & 106.0 & 108.0 & 84.5 & -26.5 & -21.5 \\
4. & 133.0 & 97.0 & 90.0 & 82.5 & -43.0 & -15.5 \\
5. & 125.0 & 60.0 & 111.0 & 66.5 & -14.0 & +6.5 \\
6. & 129.5 & 67.5 & 95.5 & 59.0 & -34.0 & -8.5 \\
\hline Mean & 143.4 & 88.0 & 109.4 & 80.46 & -34.0 & -7.7 \\
\hline
\end{tabular}

It is thus evident that, although total circulating albumin falls, the loss of water from the blood stream more than compensates, so that a normal concentration is approached. Now, when the amount of albumin available from extracellular fluid is calculated by multiplying its concentration per liter by the loss of extracellular fluid in liters, an average value of 73.9 grams is obtained. Since the average loss in the blood stream itself is 34.0 grams, this, added to the amount available from decreased extracellular fluid, gives a mean total of 99.9 grams unaccounted for, a value of 3.63 grams per each $100 \mathrm{cc}$. of blood. Such a quantity of protein cannot remain in extracellular fluid in the recovery phase. Urinary loss of proteins in these patients was negligible. Since nitrogen balances were not done, we have no idea how much was metabolized but the changes noted are in harmony with the work of Madden and Whipple (32), which shows that serum proteins are in a state of flux. Madden and Whipple have stated that "The tacit assumption has been that, once formed, unless obviously lost by .... transudation . . . plasma protein is static. . . . A steady state of ebb and flow exists between it and a portion of the cell and tissue body protein." It is inconceivable that as much as 150 grams of protein (Case 5) could be left in extracellular space for any length of time, especially with reduction in volume of extracellular fluid. Ap- 
parently, this large amount of protein, which was returned to the blood stream via the lymphatics, is stored for future use, presumably in the liver and reticulo-endothelium. Such a concept is wholly in accord with Whipple's work on plasmapheresis. This "dynamic equilibrium" of serum proteins holds not only for slow changes but for rapid changes as well. Stewart and Rourke (33), studying changes in sixteen patients undergoing ether anaesthesia and surgical procedures, showed a mean reduction of plasma volume of 13.8 per cent and a mean increase in extracellular fluid of drawn without stasis at the start of the first period of urine collection and at twenty-minute intervals thereafter until the close of the experiment. Mid-point concentrations were determined by interpolation, and mean concentration for each period was measured by the use of a planimeter.

Inulin concentration in plasma and urine was measured by the method of Corcoran and Page (34). Phenol red concentration was determined in alkalinized samples of plasma and urine by the use of a Pulfrich photometer, with an S-53 filter. Occasional minimal hemolysis was corrected by using an $\mathrm{S}-43$ filter which shows no light absorption with phenol red in the concentrations used but which shows 2.5 times as much absorption with alka-

TABLE VI

Measurements of renal function in congestive failure and after compensation

\begin{tabular}{|c|c|c|c|c|c|c|c|}
\hline Case & $\begin{array}{l}\text { Blood urea } \\
\text { nitrogen }\end{array}$ & $\begin{array}{c}\text { Maximum } \\
\text { specific } \\
\text { gravity } \\
\end{array}$ & $\begin{array}{l}\text { Inulin } \\
\text { clearance }\end{array}$ & $\begin{array}{l}\text { Phenol red } \\
\text { clearance }\end{array}$ & $\begin{array}{c}\text { Urea } \\
\text { clearance }\end{array}$ & $\frac{\text { Phenol red }}{\text { Inulin }}$ & \\
\hline 1. F. T. & $\begin{array}{l}23.2 \\
18.4\end{array}$ & $\begin{array}{l}1.030 \\
1.028\end{array}$ & $\begin{array}{r}107 \\
91\end{array}$ & $\begin{array}{l}144 \\
238\end{array}$ & $\begin{array}{c}\text { per cent of } \\
\text { normal } \\
36 \\
67\end{array}$ & $\begin{array}{l}1.3 \\
2.6\end{array}$ & $\begin{array}{l}\text { In failure. } \\
\text { Compensated. }\end{array}$ \\
\hline 2. P. K. & $\begin{array}{l}18.6 \\
18.1\end{array}$ & $\begin{array}{l}1.023 \\
1.020\end{array}$ & $\begin{array}{l}61 \\
83\end{array}$ & $\begin{array}{r}75 \\
280\end{array}$ & $\begin{array}{l}56 \\
78\end{array}$ & $\begin{array}{l}1.2 \\
4.4\end{array}$ & $\begin{array}{l}\text { In failure. } \\
\text { Compensated. }\end{array}$ \\
\hline 3. J.F. & $\begin{array}{l}13.0 \\
25.9\end{array}$ & $\begin{array}{l}1.019 \\
1.024\end{array}$ & $\begin{array}{l}69 \\
88\end{array}$ & $\begin{array}{l}150 \\
191\end{array}$ & $\begin{array}{l}69 \\
74\end{array}$ & $\begin{array}{l}2.2 \\
2.2\end{array}$ & $\begin{array}{l}\text { In failure. } \\
\text { Compensated. }\end{array}$ \\
\hline 4. W. T. & $\begin{array}{l}18.5 \\
25.3\end{array}$ & $\begin{array}{l}1.017 \\
1.020\end{array}$ & $\begin{array}{l}74 \\
68\end{array}$ & $\begin{array}{l}155 \\
228\end{array}$ & $\begin{array}{l}67 \\
39\end{array}$ & $\begin{array}{l}2.1 \\
3.3\end{array}$ & $\begin{array}{l}\text { In failure. } \\
\text { Compensated. }\end{array}$ \\
\hline 5. M. A. & $\begin{array}{l}10.5 \\
23.7\end{array}$ & $\begin{array}{l}1.022 \\
1.022\end{array}$ & $\begin{array}{r}95 \\
105\end{array}$ & $\begin{array}{l}178 \\
311\end{array}$ & $\begin{array}{l}64 \\
37\end{array}$ & $\begin{array}{l}1.9 \\
3.0\end{array}$ & $\begin{array}{l}\text { In failure. } \\
\text { Compensated. }\end{array}$ \\
\hline 6. J. Y. & $\begin{array}{l}18.0 \\
13.5\end{array}$ & $\begin{array}{l}1.021 \\
1.016\end{array}$ & $\begin{array}{l}40 \\
87\end{array}$ & $\begin{array}{r}85 \\
238\end{array}$ & $\begin{array}{l}36 \\
59\end{array}$ & $\begin{array}{l}2.1 \\
2.7\end{array}$ & $\begin{array}{l}\text { In failure. } \\
\text { Compensated. }\end{array}$ \\
\hline
\end{tabular}

27.5 per cent; the mean reduction in plasma protein concentration, however, was only 0.5 gram per cent.

\section{Kidney function}

Kidney function during decompensation and after recovery was estimated by inulin, phenol red and urea clearances, and maximum specific gravity.

In the clearance studies, three or more urine specimens were collected at thirty-minute intervals by means of an indwelling urethral catheter. At the end of each period of urine collection, the bladder was washed with a measured amount of normal saline. One-half hour before the start of the first period of urine collection, $150 \mathrm{cc}$. of a 4 per cent solution of inulin were given intravenously. At the same time, $3 \mathrm{cc}$. of a 10 per cent solution of phenol red were given intramuscularly. In this manner, the clearances were done upon a falling blood concentration of the injected substances. Venous blood was with- line hematin as does the S-53 filter. Urea content of urine was determined by the manometric urease method of Van Slyke (35) and that of blood by the hypobromite method of Van Slyke and Kugel (36). Plasma concentrations of inulin ranged from 61 to $10 \mathrm{mgm}$. per $100 \mathrm{cc}$., and of phenol red from 1.17 to $0.24 \mathrm{mgm}$. per $100 \mathrm{cc}$. These concentrations of phenol red are below those at which "self depression" of the clearance takes place (37).

The changes in maximum specific gravity, mean inulin, phenol red, and urea clearances in these patients are shown in Table VI. For purposes of discussion, the inulin clearance may be regarded as a measure of the volume of glomerular filtrate and the phenol red clearance as a measure of renal blood flow, or "effective" renal blood flow in Smith's terminology (37). Smith has abandoned the phenol red clearance in favor of the diodrast clearance for this purpose since the latter has the 
higher plasma clearance (38). Both substances are excreted chiefly by secretory activity of the tubule cells, and both show depression of clearance values with increase in blood concentration. Since, however, Smith finds a fairly constant ratio between diodrast and phenol red clearances in the normal kidney when the plasma levels are low, it seems legitimate in this instance to use the latter as an indication of changes in renal blood flow. The presence of appreciable numbers of intrarenal arteriovenous anastomoses described by Spanner (39) would, of course, invalidate this assumption if these were uniformly open during decompensation and closed with recovery.

While the mean inulin clearance is numerically greater after compensation in four of the six patients, this is statistically significant only in Case 6 (J. Y.). The phenol red clearance as an indication of renal blood flow is numerically greater in all cases, and the difference is significant in all but Case 3 (J. F.). The urea clearance is also increased after cardiac compensation, but the significance is difficult to estimate since the majority of observations during decompensation were made with urine flows of less than $2 \mathrm{cc}$. per minute (standard clearance), while many of those after compensation represent maximum clearances.

If the phenol red clearance may be regarded as a measure of renal blood flow, it is possible to calculate any change in the fraction of the cardiac output which goes to the kidneys with restoration of compensation. In Case 1, the phenol red clearance represents 6.4 per cent of the cardiac output during cardiac failure, and 6.1 per cent after restoration of compensation. In Case 2, the values are 2.6 and 7.2 per cent; in Case 3, 6.0 and 5.5 per cent; in Case 4, 5.7 and 6.3 per cent; in Case 5, 5.7 and 8.0 per cent; and in Case 6, 4.1 and 6.1 per cent, giving an average of 5.1 per cent during failure and 6.5 per cent after recovery. Thus, the phenol red clearance represents about the same fraction of the cardiac output both during failure and after improvement. If the usual ratio between phenol red and diodrast clearance found by Smith be assumed, and minimal renal blood flow calculated from this and hematocrit, the conclusion is unchanged : renal blood flow both during failure and after improvement represents about 20 per cent of the estimated cardiac output. This corresponds with the average of 29 per cent found by Smith, Goldring, and Chasis (38) for normal persons receiving a constant intravenous infusion.

The constancy of the inulin clearance with changes in renal blood flow implies changes in glomerular capillary pressure and in the fraction of the plasma filtered. An increase in glomerular capillary pressure during decompensation might be brought about by an increased tone (constriction) of the efferent vessel, dilatation of afferent vessel, or by increased pressure in the renal vein. The existence of the former mechanism of control of capillary pressure was described by Richards and Plant (40) and has been assumed by Chasis, Ranges, Goldring and Smith (41) to be an important mechanism in regulating the renal circulation. Smith finds the inulin clearance constant in normal kidneys both during adrenalin ischemia and pyrexial hyperemia, in spite of changes in the diodrast clearance which is used as a measure of renal blood flow. Constriction of efferent vessel diminishes renal flow. If this mechanism is responsible for the constant inulin clearance, it implies that were such constriction not present a greater fraction of the cardiac output would go to the kidneys in the decompensated patient than in the normal patient. No mechanism to account for such a hypothesis is apparent. If, however, only efferent vessels take part in the generalized increase in peripheral resistance of cardiac failure, the data could be accounted for on such a basis. Afferent vessels, however, respond in the usual way to central and chemical constriction or stimuli. Similarly, dilatation of afferent vessels, other conditions remaining the same, gives an increased renal flow (42) and glomerular pressure. The constant percentage of the cardiac output represented by the phenol red clearance would seem to make this mechanism unlikely. The higher diastolic pressure and calculated peripheral resistance during decompensation are probably an indication of arteriolar constriction, so that if afferent arterioles were dilated, their state would have to be assumed to differ from that of other small arteries in the body.

In hyperthyroidism (Table VII), both phenol red and inulin clearances represent about the same fraction of the cardiac output before and after thyroidectomy, and the phenol red/inulin ratio is 
unchanged, so that here it seems unnecessary to postulate any changes in intrarenal vascular adjustments.

Hence, it seems that the simplest explanation of the data on the cardiac patients is that renal blood flow is reduced in proportion to the reduction in cardiac output, and that the high venous pressure is responsible for an abnormally high

TABLE VII

Changes in renal function before and after thyroidectomy for hyperthyroidism

\begin{tabular}{|c|c|c|c|c|c|}
\hline Case & $\begin{array}{c}\text { Inulin } \\
\text { clearance }\end{array}$ & $\begin{array}{l}\text { Phenol } \\
\text { red } \\
\text { clearance }\end{array}$ & Phenol red/Inulin & $\begin{array}{c}\text { Urea } \\
\text { clearance }\end{array}$ & $\begin{array}{c}\text { Blood } \\
\text { urea } \\
\text { nitrogen }\end{array}$ \\
\hline 1. & $\begin{array}{l}183 \\
128\end{array}$ & $\begin{array}{l}367 \\
322\end{array}$ & $\begin{array}{l}2.0 \\
2.5\end{array}$ & $\begin{array}{c}\text { percent } \\
144 \\
107\end{array}$ & $\begin{array}{l}7.6 \\
4.4\end{array}$ \\
\hline 2. & $\begin{array}{l}117 \\
110\end{array}$ & $\begin{array}{l}392 \\
345\end{array}$ & $\begin{array}{l}3.3 \\
3.1\end{array}$ & $\begin{array}{l}80 \\
80\end{array}$ & $\begin{array}{r}17.3 \\
9.9\end{array}$ \\
\hline 3. & $\begin{array}{l}167 \\
120\end{array}$ & $\begin{array}{l}572 \\
395\end{array}$ & $\begin{array}{l}3.4 \\
3.3\end{array}$ & $\begin{array}{l}97 \\
80\end{array}$ & 15.0 \\
\hline
\end{tabular}

glomerular capillary pressure with a consequent increase in the fraction of the plasma water which is filtered.

It should be pointed out that the decrease in kidney function accompanying heart failure is not associated with any decrease in concentrating power, so that there is no evidence that the passive congestion and diminished blood flow have impaired tubular function. Since these cells are carrying out their usual function normally, it may be presumed that the ability to secrete phenol red is likewise unimpaired. The mean phenol red/inulin clearance ratio in these patients after recovery was 3.0 , which is slightly lower than the average of 3.3 given by Smith.

\section{SUM MARY}

Estimations of cardiac output, volume of blood and interstitial fluid, concentration and total amount of plasma proteins, and of inulin, phenol red and urea clearances were made on six patients with congestive heart failure and again after restoration of compensation by digitalis and diuretics.

Cardiac output and stroke volume increased with improvement in all cases. The mean minute output during failure was 31 per cent less than after improvement. Effective peripheral resistance decreased coincidentally with improvement.
Blood and serum volumes also decreased with recovery, the mean change in blood volume being 1.15 liters or 25 per cent, and in serum volume 0.92 liter or 35 per cent of the volumes during failure. In spite of a marked decrease in the volume of intercellular fluid, the mean value after restoration of compensation was 32 per cent of total body weight, or almost 50 per cent above normal.

While the concentration of serum proteins, particularly of the globulin fraction, increased with clinical improvement, the total amount of circulating protein decreased, due almost entirely to a decrease in serum albumin.

Inulin clearance showed no significant change with improvement, while phenol red clearance increased to approximately the same degree as the cardiac output.

\section{PROTOCOLS}

Case 1, F. T., Hospital Number 201-250. A 66-yearold Italian laborer entered the hospital on November 25 , 1939, because of dyspnea and edema of legs. He had had mild symptoms of failure for two years. Two months prior to admission, dyspnea became severe and he developed generalized edema. He had taken no digitalis. Physical examination showed a large heart, a large tender liver, and edema of both extremities with a large abdomen without demonstrable fluid. Pulse was 110 and blood pressure was $240 / 140$. Vital capacity was 1,200 cc. After the data were obtained, he was digitalized, responding with a fair diuresis and relief of symptoms. On his sixth hospital day he developed pneumonia, which responded well to sulfapyridine, and he was discharged symptomatically improved and edema free after the second set of determinations were performed twenty-eight days later. Blood pressure on discharge was 180/110. Diagnosis: Hypertensive heart disease and cardiac decompensation.

Case 2, P. K., Hospital Number 201-932. A 71-yearold white male entered the hospital on December 27, 1939, because of dyspnea and edema of the legs. Eight years previously he had had mild symptoms of failure, and three years previously he had had symptoms suggestive of a myocardial enfarct. He had received digitalis intermittently with relief of symptoms, but two months before admission edema became more noticeable and had recently become massive. He had taken no digitalis within three weeks. On physical examination the heart was enlarged, there were pleural effusions at both lung bases, the abdomen contained fluid, and massive pitting edema extended from the ankles to the scrotum. Pulse was 90 and blood pressure 160/90. Vital capacity was 2,000 cc. The patient was digitalized and obtained symptomatic improvement. On several occasions salyrgan administration 
resulted in a copious diuresis. 'He was discharged edema free after twenty-six days in the hospital. Blood pressure on discharge was 140/80. Diagnosis: Arteriosclerotic heart disease with cardiac decompensation.

Case 3, J. F., Hospital Number 202-176. A 72-yearold white man was admitted on January 8, 1940, complaining of sudden onset of dyspnea and edema two weeks previously. Physical examination showed marked orthopnea, right hydrothorax, and numerous râles over the left lung. The heart was enlarged $12 \mathrm{~cm}$. to the left of the mid-sternal line. A harsh systolic murmur was present over the entire precordium but was best heard over the second interspace just to the right of the sternum. Blood pressure was $165 / 95$. The liver was palpable 5 $\mathrm{cm}$. below the costal margin and was tender. There was pitting edema to the level of the sacrum. Peripheral arteriosclerosis was marked. He was treated with digitalis and mercurial diuretics with marked improvement and was discharged on his thirty-first hospital day with a blood pressure of $150 / 95$ and free from demonstrable edema. Diagnosis: Arteriosclerotic heart disease with hypertension and cardiac decompensation.

Case 4, J. G., Hospital Number 210-731. A 52-yearold white man was admitted on January 8, 1941, with the history of ankle edema and dyspnea on exertion of three months' duration. There was slight arteriovenous notching of the vessels of the fundi. Moist râles were present over the bases of both lungs. The heart was enlarged; no murmurs were heard; blood pressure was 210/118. The liver was palpable three fingers' breadth below the costal margin. Pitting edema was present to the level of the sacrum. He was treated with digitalis and mercurial diuretics and showed a satisfactory response. $\mathrm{He}$ was discharged on his forty-second hospital day with a blood pressure of $160 / 90$ and free from demonstrable edema. Diagnosis: Hypertensive cardiovascular disease with cardiac decompensation.

Case 5, M. A., Hospital Number 205-085. A 70-yearold white man was admitted on May 20,1940, with the complaint of swelling of the legs and abdomen of three months' duration. Physical examination showed cyanosis, arteriovenous notching of the retinal vessels, moist râles at the left lung base. The heart was enlarged $14 \mathrm{~cm}$. to the left of the mid-sternal line. There was a protodiastolic gallop rhythm. No murmurs were heard. Blood pressure was $140 / 90$. The liver was tender and palpable $5 \mathrm{~cm}$. below the costal margin. A fluid wave was present in the abdomen. Generalized arteriosclerosis was marked. There was edema of the legs to the level of the sacrum. Satisfactory compensation was obtained with digitalis and mercurial diuretics. $\mathrm{He}$ was discharged on the twenty-sixth hospital day with a blood pressure of 140/90 and free from demonstrable edema. Diagnosis: Arteriosclerotic heart disease with cardiac decompensation.

Case 6, J. Y., Hospital Number 208-229. A 65-year-old white man was admitted on September 18, 1940, with the chief complaints of dyspnea on exertion and swelling of the legs of four months' duration. Physical examination showed moderate cyanosis, distended neck veins, and râles over both lower lobes of the lungs. The heart was enlarged $13 \mathrm{~cm}$. to the left of the mid-sternal line, and 5 $\mathrm{cm}$. to the right. A systolic murmur was present at the apex. Blood pressure was $142 / 100$. The liver was enlarged, extending $8 \mathrm{~cm}$. below the costal margin and was tender. There was pitting edema of the legs to the level of the sacrum. The peripheral arteries were markedly sclerotic. Satisfactory compensation was obtained with digitalis and mercurial diuretics and he was discharged on the thirty-third hospital day with a blood pressure of 190/60 and free from demonstrable edema. Diagnosis: Arteriosclerotic heart disease with cardiac decompensation.

\section{BIBLIOGRAPHY}

1. Stewart, H. J., and Cohn, A. E., Studies on the effect of the action of digitalis on the output of blood from the heart. J. Clin. Invest., 1932, 11, 917.

2. Starr, I., Jr., and Gamble, C. J., Cardiac output in common clinical conditions, and the diagnosis of myocardial insufficiency by cardiac output methods. Ann. Int. Med., 1935, 9, 569.

3. MacKenzie, Sir James, Diseases of the Heart. Oxford Univ. Press, London, 1925.

4. Lewis, Sir Thomas, Diseases of the Heart. MacMillan Company, New York, 1933.

5. Friedman, B., Clark, G., Resnik, H., and Harrison, T. R., Effect of digitalis on the cardiac output of persons with congestive heart failure. Arch. Int. Med., 1935, 56, 710.

6. Harrison, T. R., Failure of the Circulation. Williams and Wilkins, Baltimore, 1939, 2nd ed.

7. Fishberg, A. M., Heart Failure. Lea and Febiger, Philadelphia, 1937.

8. Richards, A. N., and Plant, O. H., Urine formation in the perfused kidney. The influence of alterations in renal blood pressure on the amount and composition of urine. Am. J. Physiol., 1922, 59, 144.

9. Grollman, A., The Cardiac Output of Man in Health and Disease. C. C. Thomas, Baltimore, 1932.

10. Bazett, H. C., Cotton, F. S., LaPlace, L. B., and Scott, J. C., The calculation of cardiac output and effective peripheral resistance from blood pressure measurements with an appendix on the size of the aorta in man. Am. J. Physiol., 1935, 113, 312.

Bazett, H. C., Scott, J. C., Maxfield, M. E., and Blithe, M. D., Calculation of cardiac output from blood pressure measurements before and after meals. Am. J. Physiol., 1936, 116, 551.

11. Whittaker, R. F., and Winton, F. R., The apparent viscosity of blood flowing in an isolated hindlimb of the dog, and its variations in corpuscular content. J. Physiol., 1933, 78, 339.

12. Gregg, D. E., Eckstein, R. W., and Fineberg, M. H., Pressure pulses and blood pressure values in unanesthetized dogs. Am. J. Physiol., 1937, 118, 399. 
13. Lyons, R. H., Kennedy, J. A., and Burwell, C. S., The measurement of venous pressure by the direct method. Am. Heart J., 1938, 16, 675.

14. Wiggers, C. J., The dynamics of hypertension. Am. Heart J., 1938, 16, 515.

15. Bazett, H. C., Blood volume and cardiovascular adjustments, Am. Heart J., 1941, 21, 423.

16. Starr, I., Rôle of the "static blood pressure" in abnormal increments of venous pressure, especially in heart failure. Am. J. Med. Sc., 1940, 199, 1.

17. Payne, S. A., and Peters, J. P., The plasma proteins in relation to blood hydration. VIII. Serum proteins in heart disease. J. Clin. Invest., 1932, 11, 103.

18. Cope, C. L., The osmotic pressure of the blood proteins in nephritis. Quart. J. Med., 1928, 22, 91.

19. Epstein, A. A., A contribution to the study of the chemistry of blood serum. J. Exper. Med., 1912, 16, 719.

20. Thomson, W. R. A., The plasma proteins and cardiac oedema. Quart. J. Med., 1934, 3, 587.

21. Hand, H. M., Concentration of serum protein in different types of edema. Arch. Int. Med., 1934, 54, 215.

22. Rowe, A. H., Refractometric studies of serum proteins in nephritis, cardiac decompensation, diabetes, anemia, and other chronic diseases. Arch. Int. Med., 1917, 19, 354.

23. Ellis, L. B., Plasma protein deficiency in patients with cardiac edema. Med. Clin. North Amer., 1933, 16, 943.

24. Iversen, P. U., and Nakazawa, F., Utber die Biochemie Des Filtrationsödems. Biochem. Ztschr., 1927, 191, 307.

25. Unpublished data from the laboratory of Dr. J. P. Peters, New Haven Hospital.

26. Loeb, R. F., Plasma proteins in health and disease. New England J. Med., 1941, 224, 980.

27. Gibson, J. G., 2nd, and Evans, W. A., Jr., Clinical studies in blood volume. III. Changes in blood volume, venous pressure, and blood velocity rate in chronic congestive heart failure. J. Clin. Invest., 1937, 16, 851.

28. Gibson, J. G., 2nd, and Evans, W. A., Jr., Clinical studies in blood volume. I. Clinical application of a method employing the azo dye "Evans Blue" and the spectrophotometer. J. Clin. Invest., 1937, 16, 301 .
29. Lavietes, P. H., Bourdillon, J., and Klinghoffer, K. A., The volume of the extracellular fluids of the body. J. Clin. Invest., 1936, 15, 261.

30. Robinson, H. W., Price, J. W., and Hogden, C. G., The estimation of albumin and globulin in blood serum. III. The precipitation of globulin at twentyfive degrees by sodium sulfate. J. Biol. Chem., 1938, 126, 213.

Robinson, H. W., Price, J. W., and Hogden, C. G., The estimation of albumin and globulin in blood serum. II. Separation of fractions by centrifugation with the angle centrifuge. J. Biol. Chem., 1938, 126, 207.

31. Landis, E. M., The passage of fluid through the capillary wall. Am. J. M. Sc., 1937, 193, 297.

32. Madden, S. C., and Whipple, G. H., Plasma proteins : Their source, production, and utilization. Physiol. Rev., 1940, 20, 194.

33. Stewart, J. D., and Rourke, G. M., Changes in blood and interstitial fluid resulting from surgical operation and ether anaesthesia. J. Clin. Invest., 1938, 17, 413.

34. Corcoran, A. C., and Page, I. H., Application of diphenylamine in the determination of levulose in biological media. J. Biol. Chem., 1939, 127, 601.

35. Van Slyke, D. D., Determination of urea by gasometric measurement of the carbon dioxide formed by the action of urease. J. Biol. Chem., 1927, 73, 695.

36. Van Slyke, D. D., and Kugel, V. H., Improvements in manometric micro-Kjeldahl and blood urea methods. J. Biol. Chem., 1933, 102, 489.

37. Smith, H. W., The Physiology of the Kidney. Oxford University Press, New York, 1937.

38. Smith, H. W., Goldring, W., and Chasis, H., The measurement of the tubular excretory mass, effective blood flow and filtration rate in the normal human kidney. J. Clin. Invest., 1938, 17, 263.

39. Spanner, R., Der Abkürzungskreislauf der menschlichen Niere. Klin. Wchnschr., 1937, 16, 1421.

40. Richards, A. N., and Plant, O. H., Urine formation in the perfused kidney. The influence of adrenalin on the volume of perfused kidney. Am. J. Physiol., 1922, 59, 184.

41. Chasis, H., Ranges, H. A., Goldring, W., and Smith, H. W., The control of renal blood flow and glomerular filtration in normal man. J. Clin. Invest., 1938, 17, 683.

42. Richards, A. N., The nature and mode of regulation of glomerular function. Am. J. M. Sc., 1925, 170, 781. 